\title{
A New Record of Genus Halichondria (Demospongiae: Halichondrida: Halichondriidae) from Korea
}

\author{
Yong Jin Jeon and Chung Ja Sim* \\ Department of Biological Engineering, College of Life Sciences and Nano Technology, \\ Hannam University, Daejeon 305-811, Korea
}

\begin{abstract}
Marine sponges were collected from Tongyeong yachtschool harbor, Korea in 2008. Among them Halichondria (Halichondria) bowerbanki Burton, 1930 is newly recorded in the Korean fauna.
\end{abstract}

Key words: Halichondriidae, Halichondria, Korea

\section{INTRODUCTION}

The genus Halichondria is characterized by ectosomal skeleton which consists of thin, tangential, clearly detachable membrane, containing single oxeas or vague bundles of oxeote spicules and it supported by choanosomal columns of oxeas traversing subdermal spaces (Hooper, 1994). Megascleres exclusively oxeas or derivates are in a wide size range. About 110 species are distributed worldwide (Hooper and van Soest, 2002). Seven species of Halichondria have been reported from Korean waters (Kim et al., 1968; Rho and Lee, 1976; Kang and Sim, 2008a, b). The specimens were collected by hand from Tongyoung, Korea in 2008. All procedures were followed the methods of Kang and Sim (2008b) and Rützler (1978). The materials examined in this study were deposited in the Natural History Museum and Department of Biological Sciences, Hannam University, Daejeon, Korea.

\section{SYSTEMATIC ACCOUNTS}

Phylum Porifera Grant, 1836

Class Demospongiae Sollas, 1885

Order Halichondrida Gray, 1867

Family Halichondriidae Gray, 1867

${ }^{1 * H a l i c h o n d r i a}$ (Halichondria) bowerbanki Burton, 1930 (Fig. 1)

Halichondria bowerbanki Burton 1930, p. 489; Lee et al.,

*To whom correspondence should be addressed

Tel: 82-42-629-8755, Fax: 82-42-629-8751

E-mail: cjsim@hnu.kr
Table 1. Comparison in spicule dimension of $H_{\text {. }}\left(H_{.}\right)$bowerbanki

\begin{tabular}{|c|c|c|}
\hline Spicule $(\mu \mathrm{m}) \quad$ Species & H. (H.) bowerbanki & $\begin{array}{l}\text { Tongyeong } \\
\text { specimen }\end{array}$ \\
\hline Oxeas & $200-330 \times 3-12$ & $170-380 \times 2-10$ \\
\hline
\end{tabular}

2002, p. 79.

Material examined. Yachtschool harbor, Tongyeong-si, Gyeongsangnam-do, 14 Nov. 2008.

Description. Encrusting, attached to substrate with irregular branches which shaped like tassel reaching 2-6 cm high, solid and gets thiner to the end. Oscules opened at the ends of each branch with $2-5 \mathrm{~mm}$ in diameter. Surface smooth. Texture torn. Colour yellow in life gradually changed to ivory in alcohol. Ectosomal skeleton reticularly confused. Choanosomal skeleton irregularly reticulated. Spicules, megascleres, oxea. No microscleres.

Spicules

Megascleres

Oxeas $170-380 \times 2-10 \mu \mathrm{m}$

Remarks. Oxeas of our specimen are slightly larger than $H$. (H.) bowerbanki's (Table 1).

Distribution. Korea, Central California, Europe (Monaco, North Coast of France, North Coast of Norway, Svalbard, United Kingdom).

\section{ACKNOWLEDGEMENTS}

This work was supported by the Invasive Species Management Program in Marine Ecosystem (2008), Korean Mini-

$1 *$ 보어밴키해변해면 (신칭) 

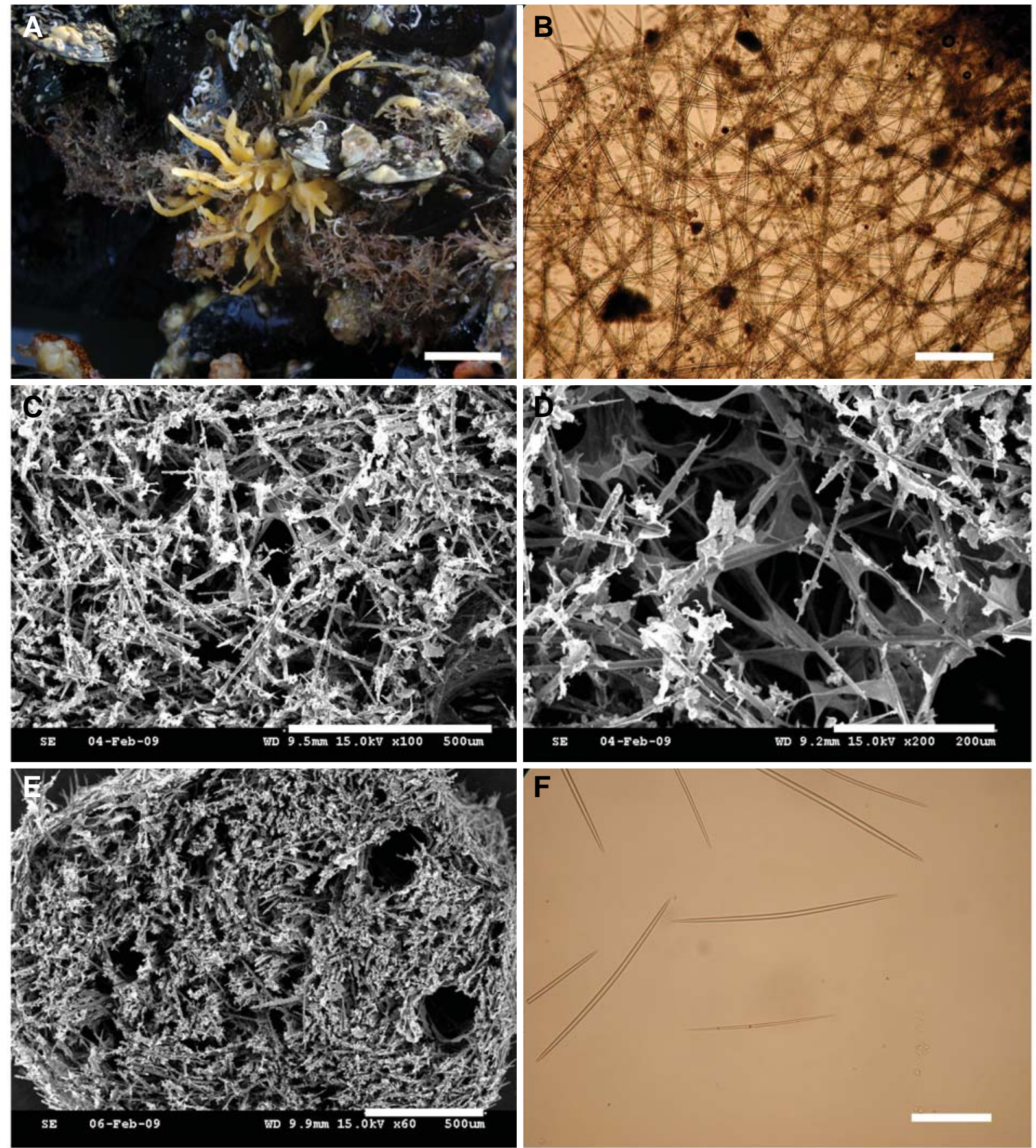

Fig. 1. Halichondria (Halichondria) bowerbanki. A, entire animal; B, ectosomal skeleton; C-D, choanosomal skeleton; $E$, across section of branch; F, oxeas. Scale bars $=3 \mathrm{~cm}$ (A); $500 \mu \mathrm{m}$ (C-E); $300 \mu \mathrm{m}$ (B); $200 \mu \mathrm{m}$ (D); $150 \mu \mathrm{m}$ (F).

stry of Land, Transport and Maritime Affairs.

\section{REFERENCES}

Burton, M. 1930. Additions to the sponge fauna at Plymouth. J.
Mar. Biol. Ass. U. K., 16(2): 489-507.

Hooper, J.N.A., 1994. Guide to sponge collection and identification. Mem. Queensl. Mus., pp. 1-99.

Hooper J.N.A. and R.W.M. van Soest, 2002. Systema Porifera. A Guide to the Classification of Sponges. Vol. 1. Kluwer Academic/Plenum Publishers, Press, USA, pp. 1-1101. 
Kang, D.W. and C.J. Sim, 2008a. Two new sponges of the genus Halichondria (Halichondrida: Halichondriidae) from Korea. Animal Cells and Systems, 12(1): 65-68.

Kang, D.W. and C.J. Sim, 2008b. Two new marine sponges of genus Halichondria (Halichondrida: Halichondriidae) from Korea. Korean J. Syst. Zool., 24(2): 205-208.

Kim, H.S., B.J. Rho and C.J. Sim, 1968. Marine sponges in South Korea (1). Korean J. Zool., 11(2): 37-48.

Lee, W.L., D.W. Elvin and H.M. Reiswig, 2007. A Guide and Key to the Marine Sponges of California, pp. 1-265.
Rho, B.J. and K.H. Lee, 1976. A survey of marine sponges of Haeundae and its adjacent water. J. Kor. Res. Inst. Better Liv. Ewha Womans Univ., 17: 93-111.

Rützler, K., 1978. Sponges in coral reefs. In Stoddart, D.R. and R.E. Johannes eds., Coral Reefs: Research Methods. Monogr. Oceanogr. Neth. UNESCO, pp. 299-313.

Received February 16, 2009 Accepted March 11, 2009 